\title{
ORGANIZATIONAL STRUCTURES WITHIN THE SCOPE OF STRATEGIC MARKETING PLANNING: A DISCURSIVE STUDY
}

Envio 09.10.08 / Aceite 19.04.09

\section{Luciano Augusto Toledo ${ }^{1}$}

\begin{abstract}
The present article proposes to analyze marketing planning within the context of innovative organizational structures. The work has been structured as an essay, and is comprised of a review of the theoretical reference, set against a conceptual critical analysis of a few aspects pertinent to the theme. Issues around the difference among the several strategic levels, such as the formulation of corporate strategies, competitive and structural. Additionally, marketing planning activities were situated in companies' structural hierarchizing. Lastly, a reflection is conducted, raising issues adjacent to marketing planning, strategies, and innovative organizational structures.
\end{abstract}

Key words: Organizational structure, marketing planning, strategies.

${ }^{1}$ Doutor em Administraçao pela FEA-USP - Professor da Universidade Mackenzie - Av. Luciano Gualberto, 908 Sala E 106 - Butantã - SP - SP - 1192008067. 


\section{Introduction}

This essay tries to analyze the problems in marketing planning activities, in face of the problem posed by the existence of innovative organizational structures. Lambin (2000) is emphatic in stating that the revolution through which the world is going is notorious, as well as how this affects the lives of corporations. On the one hand, the phenomenon of globalization unfolds and, on the other, the technological evolution led by the use of the Internet and other emerging technologies. The constant and uncontrollable changes that occur in the contemporary business environment demand permanent adaptations and adjustments in productive and administrative products and processes, and those who do not attempt to adequate to the new environmental conditions will face difficulties to grow and survive. Companies are exposed to drastic changes in managerial and cultural paradigms, and many are disoriented and pathless in the face of the situations prevalent in the external environment. In this technical-cultural revolution scenario, strategic planning and marketing planning stand out as guiding instruments for the improvement of company competitiveness, push forth the growth of the organization and articulate changes in organizational structures.

In this sense, all and any changes in configuration in an organizational structure may or may not bring about improvements, innovative configurations. Thus, the aforementioned justifies a scientific study dealing with some of the specificities of the theoretical references that base the concepts of strategic and marketing planning in the scope of innovative organizational structure.

\subsection{Work method}

The work is structured as an essay, which is conceived by Medeiros (2000) as a methodological narrative on a subject and the offering of original conclusions reached after accurate examination of such subject, based on documented evidence. For the author, the essay is, by nature, "problematic rendering" and non-dogmatic, and in it, the author's critical spirit and newness, or better, originality, should prevail. As Severino (2000) ponders, in the essay the author is more free to defend a certain position, without having to sustain the rigorous and objective apparatus of empirical and bibliographical evidence.

In fact, the essay does not dismiss the logical rigor and coherence of argumentation and, for this very reason, demands cultural information and intellectual maturity. The present essay proposes to undertake a formal, discursive and conclusive analysis and unfolds into a logical and reflexive narrative on strategic and marketing planning, and the model of innovative organizational structures.

\section{Theoretical reference}

\subsection{Corporate srategies}

A characteristic of strategic strategies is to assure the accomplishment of the company's growth objectives over time, by evaluating the present and intended strategic business units 
and carrying out a strategic analysis for resource allocation. The aim of those strategies is to decide on the business transactions a company will undertake and the amount of resources necessary o maintain them. There are five possible growth strategies for a company, of which three are related to intensive growth (KOTLER and KELLER, 2006; ANSOFF, 1957), and are described bellow. Intensive growth strategies are aimed at identifying growth opportunities for the companies' present business and can be configured as, market penetration, market development and product development. The integrated growth strategy is aimed at identifying growth opportunities in business transactions related to the present ones. They may try to acquire companies upstream or downstream, or try to accomplish horizontal integration through consolidations or takeovers. Finally, the company can choose a diversified growth strategy, where it tries to identify growth opportunities in businesses unrelated to the present ones (HOOLEY, SAUNDERS and PIERCY, 2005).

The decision to invest in a company will depend on the structure of the industry analyzed, on a case-by-case basis. Porter (1998) defined five competitive forces that affect the attractiveness and competitiveness of a given industry. Those forces refer to the potential entrances, the sellers' and buyers' bargaining power, the threat of substitute products, and finally competition with other present companies. Hooley, Saunders and Piercy (2005) add that any diversified organization needs to find methods to appraise the balance among businesses in its portfolio and aid in resource allocation among them.

\subsection{Competitive strategies}

After defining the markets to be served by the organization, the company needs to conquer and maintain them. Porter (1998) theorizes on this position as the process for the search for a competitive or business strategy. This strategy can be reached in many ways. However, it is possible to synthesize them in two global propositions: leadership in costs and differentiation (PORTER, 1998). Competitive strategies reflect the organization's capacity to adjust in accordance with what has been identified in terms of its attractiveness and competitiveness. Besanko, Dranove and Shanley (2000) render relative those strategic positions by defining the concept of created value. While Porter (1998) argues that the best outcome is in the capacity to take advantage of the company's value chain to reduce costs or create relevant differentials for consumers, without admitting mixed situations, Dranove and Shanley (2000) argue that the organization's best outcome is supplying a created valued higher than the competition's, where the buyer's surpluses are added to the profit made by the company minus production costs.

Another important point in the formulation of competitive strategies is the concern with maintaining a competitive edge. Competitive edges can be protected through isolation mechanisms that neutralize the competition's value creation sources (BESANKO, DRANOVE and SHANLEY, 2000). These mechanisms can be a barrier against imitations (legal restrictions such as patents and copyright, exclusive access to clients, scale economies in limited markets, and intangible barriers related to historical circumstances and social complexity), or advantages resulting from quick changes (learning curves, network externalities, the brand's reputation when consumers are not sure about the product's quality, etc.)

Prahalad (2004) defends that its not enough for the company to simply carry out competitive positioning exercises. According to the author, companies should try to respond to the question of how to model their competencies in future scenarios. That is, instead of looking at past analysis, one must look, in a creative and innovative way, for new market opportunities, interactions with clients, and other relevant firms and markets. 
Gummesson (2005) proposes two phenomena that attempt to aid the understanding and formulation of the organization's competitive strategies, the systems' theory and the theory of transactional costs. In both cases, the author advocates that company's borders with clients and suppliers are not clear, but form relationships intertwined in an orderly way. The strategy, under the systemic point of view, argues that the company is in constant interaction with the environment and, therefore, all strategies must consider the client as an extension of this system. Complementing the aforementioned strategy models, the Delta Model reflects a description of the success of competitive strategies (TOLEDO, QUELOPANA and POLERO, 2005). The authors argue that this model explains and aids in the process of making strategic decisions, in the present global context. According to (HAX and MAJLUF, 1996), the Delta Model recognizes differentiation and cost leadership strategies - Best Product, but the paradigm of delivering the best product supercedes them. Additionally, according to these authors, this model foresees the strategic option of serving clients in the best way possible - Solutions for clients. This strategy allows the company to anticipate the clients' needs and increase its understanding and learning about them and, lastly, results in positive impacts upon the relationship. Finally, the model considers as an option that the company should extrapolate the organizational limits - System Lock-in. Instead of concentrating only on the product or the customer, the company considers all the elements of the system that contribute towards the creation of economic value. These elements appear as suppliers and other organizations, named complements, and are parts of the systems that supply the goods and services of the main organization (HAX and MAJLUF, 1996).

\subsection{Functional strategies}

Functional strategies are decisions subordinate to business or competitive strategies. These decisions are made in connection with the company's functional activities and administrative processes, whether they are related to the final activities, or support areas such as marketing, people management, production, finances, P \& D, information technology, etc. (HOOLEY, SAUNDERS and PIERCY, 2005).

Although these strategies are defined as a strategic level, the subordinate decisions that operationalize the search for competitive edge and growth can also be seen as action programs. This confusion results from the point-of-view adopted. At this hierarchical level, if the competitive strategy is taken as a reference, the subordinate decisions can be seen as actions to reach the objective established at the higher level. According the definition offered by Mintzberg (2002), where the programs are specific steps in actions necessary to reach the main objectives, these activities are part of the company's action program. The confusion also arises from the use of the terms "strategic plan" in the different functional areas, such as marketing, human resources, production and finances. These plans are operational and their outcome is the definition of action programs of each area, and they are subordinate to competitive strategies. One notes that the dimensions treated are totally distinguished from the company's strategic and corporate planning.

\subsection{Organizational structures}

An organizational structure can be defined as the arrangement of people and designated tasks to reach the organization's objectives (FINK, JENKS and WILLITS, 1983). This structure is the outcome of a process of division of the authority established in the company, where activities are specified and communication flows are defined. It is through this program that 
companies carry out their strategies in order to reach their aims. Galbraith (2001) completes this thought by stating that the organizational structure is designed to maintain, over time, the company's strategic choices in coherence with the established organizational goals.

Barnes et al. (1970) report and believe that companies normally use a combination of basis to group their activities and that they normally are molded around the few basis that reflect the organization's main hierarchy. According to these authors, the most common forms or grouping and hierarchizing are based on several groups such as: sectional or location, markets, products, functional specialization, processes or equipment, tasks, etc. In addition to these categories, clusters can be generated based on breadth of control and coordination capacity, among others.

Authors such as Vasconcellos and Hemsley (2002) consider that an organizational structure is comprised of three elements: authority sub-system, communication sub-system and activities sub-system, all of them managed within the clusters of people existing in the organizations. These specific clusters form units called departments. Such divisions allow the organizations' collaborators to be administered within this subsystems logic. Still according to the same authors, what defines departmentalization is the breadth of control, the hierarchical levels, the degree of decentralization, communications systems, and the company's degree of formalization. The means of formalizing such structures is through organizational charts, memos and assignments. These divisions constitute end areas or support areas, such as data processing or accounting, or such as consultancies.

Organizational structures can be classified into traditional or innovative. The first classification is more favorable in organizations whose activities are more predictable, and whose market environment is at a relatively stable stage. This form of structuring has the following characteristics (VASCONCELLOS and HEMSLEY, 2002):

A high level of formalization: the levels of authority and responsibility are detailed and thoroughly made explicit in manuals; subordinate;

Single command, the existence of only one boss or person-in-charge for each direct activities;

A high degree of specialization, people who are well trained to carry out specific

Vertical communication, communication occurs between subordinates and the boss, communication among peers is not valued;

The use of traditional types of departmentalization: Functional: the division criteria is based on the clustering of departments according to the knowledge necessary to carry out a certain activity. Geographical: Clusters collaborators in based the area in which the organization acts; Based on the Process: Clustering each stage of a process in a specific department in order to reach a high level of specialization; Clients: People who serve the same kind of client are clustered in one same area; Product/Service: People who deal with the same product are clustered in the same area; Period: Organizations that function for 24 hours a day can cluster based on the work shift, as long as the same types of activities are carried out; By control extent: used when the division is centered only on the limits of the boss' capacity to command, ex: overseer commanding sugar-cane cutters.

In many cases, traditional structures don't resist the outer environment's impacts. Due to this complexity, some organizations have begun developing more flexible structures, or structures known as innovative structures (VASCONCELLOS and HEMSLEY, 2002). With the increase in the environmental turbulence, traditional models have become bureaucratic obstacles tending towards organizational stagnation and rigidity in the capacity to respond to 
these changes. The metaphor of the mechanist, or, analogously, traditional organization, does not support the company's new needs. Other metaphors then appear, such as those based on the organic concept that has adapted to the dynamic model of survival (MORGAN, 1999), or the flexible, collaborative model, based on competencies and with horizontal communication.

Under this new reality were developed the innovative models whose structuring allows the company to respond in an agile and efficient way to the turbulence of the present competitive environment. The structural characteristics of these organizations are (VASCONCELLOS and HEMSLEY, 2002): Low level of formalization: Considering the organization's dynamics, it cannot afford the luxury of detailing each function's activities The use of advanced forms of departmentalization: Among the new forms brought to light in face of the environment, alternatives forms of departmentalization will appear, among them: Profit center - Divides the company into units with a high degree of autonomy, those responsible for act as if owners of isolated companies. Projects - People are clustered using the criteria of the project in which they are involved at that specific time. The cluster's boss is the project manager. Matrix-based - The simultaneous use of two or more types of departmentalization with the same group of people. Cellular - Characterized by the almost total absence of structure and high flexibility. New undertakings - Innovation activities are separated from routine activities. Multiple command: The single command unit cannot always be kept in these structures. As in the case of the projects of matrix-based models, conflicts between the activities proposed by each one of the bosses may occur. High Diversification: the high rate of change makes specialization more difficult. A more flexible professional is preferred to one highly specialized in one single function. Horizontal and diagonal communication: Communication occurs in all directions, considering the need for a greater volume of communication, the number of levels and the time necessary for their diffusion. Organizational structures tend to become more bureaucratic and lose flexibility as a result of the growth of the company. In order to counter balance this tendency, these companies must overcome the crisis resulting form such changes. They can be summarized in five organizational growth and development phases (GREINER, 1998): Initial creativity; Functional direction, Delegation and decentralizing; Coordination (abandoning the original functional structure, and focusing more on results); Collaboration (maturity to establish a free and flexible structure).

Each one of these phases represents a result of the relationship between the organization's size and maturity. The model foresees that, throughout the company's growth, changes in the way of thinking and acting will naturally occur, and it will begin facing moments of crisis and overcoming. These periods of time signify a transition period that results in breaking out of one phase and entering a posterior one. Greiner (1998) shows that the speed and intensity of the organization's transit through phases result from the dynamics of the industry's or sector's growth. This realization leads one to imagine that the behavior of the companies reflected in these phases adjusts to the company's growth strategies, in the sense that the more complex and faster the growth of the market, greater will be the need for organizational development.

Evidencing these organizational development phases in organizational structures, one deduces that the more advanced the growth stage, the more the organizations become structures bending towards innovation (Table 1). 
Table 1 - Organizational structure in the company's five stages of growth

\begin{tabular}{ll}
\hline Growth stages & Organizational structure \\
\hline 1 st Phase & Informal \\
$2^{\text {nd }}$ Phase & Centralized and functional \\
$3^{\text {rd }}$ Phase & Decentralized and geographical \\
$4^{\text {th }}$ Phase & Line / Consultancy and product groups \\
$5^{\text {th }}$ Phase & Matrix-based \\
\hline
\end{tabular}

Source: Adapted from Greiner (1998).

Organizational structures can be composed in many ways, depending on the companies' strategies, from classical functional structures, to the forming of cooperation nets among companies within a value system. According to Ito and Rose (2004), structures can be characterized as: functional ones split into divisions, diversification by conglomerates, diversification based on competencies, keiretsus, and alliance networks, where: Functional structures are more efficient when companies are small and have few product lines; Structures by division are clusters based on markets or products and, within each division, departments are established around the product or market at hand; Diversification by conglomerates is an organization characterized by the use of expansion strategies in the search for growth opportunities in connection to attractive markets. This form of organization behaves like an umbrella for businesses or other companies, also called strategic business units, which are successively purchased or sold, based on financial criteria; Diversification based on competencies is similar to the former, but it is more directed towards an expansion constructed upon internal competencies such as abilities, technologies, organizational learning, etc. In this form of structure, long-term actions are more valued, while in the first form one aims at equating investments and financial return; Organizations based on keirestsu have originated from family-based organizations called zaibatsu. The difference between the two is that the first is a modern conception, not based on personal ties of kinship. In keiretsu, companies create a bond of dependency and functional hierarchy around cooperation and assistance in the same way as members of a large traditional family;. The alliance networks, differently from keiretsu, are not formed by bonds of friendship and loyalty among its peers. These networks are the consequences of the adaptive necessities for the realization of complex competitive strategies that can only be carried out through joint action among organizations. They can take on several shapes, from joint ventures and cooperation contracts to the total integration of operations, the aim of which is to completely control a certain market.

\subsection{The administrative marketing process}

The functions of marketing as a instrument to facilitate exchanges take place through a set of specialized activities, which are carried out in the scope of marketing administration. According to the conception of Kotler and Keller (2006), marketing administration or management is the process of executing the conception, the determining of the price, the promotion and distribution of ideas, goods and services to create transactions that fulfil the individual and organizational objectives. Toledo and Fortes (1989), in describing the managerial dimension of marketing, that is, marketing administration, point out that some aspects should be taken into consideration. The first one of them refers to the administrative process itself. Marketing, like 
any other functional area, carries out four classic functions that comprise the administrative process: planning, organization, direction (coordination) and control.

However, the tasks and activities that comprise the decision-making process in marketing are planned, organized, coordinated, implanted and controlled by the area's managers, in the scope of an integrated management system, which should connect to all the other functional areas, with the purpose of reaching the company's objectives. In this sense, the marketing administrative process covers activities, specialized and specific tasks and functions, even if many of them are shared with the other areas that comprise the organization's inner value chain.

Nonetheless, it is important not to confuse functional marketing strategies with the organizational structures at a higher level. In this line of thought, all marketing activities dealt with bellow are at a functional decision-making level and are not an integral part of the organizational planning process as a whole.

At the operational level of these functional activities, the analysis tasks necessary to understand the market's structure and the consumer's behavior are designated by the acronym "4 O's". They involve the search for information and the understanding of four sets of issues relating to consumer behavior: object, objective, organization and operation of purchase (CAMPOMAR, 1984): Object of purchase - an analysis of what the consumer purchases, that is, the product and its multiple configurations, and brands (who to purchase from?): Objective of purchase - an analysis of the motivations, attitudes, and preferences of the buyer in the process of purchasing (why does he buy?); Organization of purchase - analysis of how the purchasing units are structured and the roles played by each member of the unit in the purchase process (who influences and who decides upon the purchase?); Operation of Purchase - is the way in which the purchase process develops and which choices can be made by the buyer as to the place (where does he buy?); the time (when does he buy?); and quantity (how much does he buy?).

The tasks that comprehend the decisions on the controllable marketing variables, or decisions on the marketing compound, at the operational level, are known under the acronym "4 P's", popularized by McCarthy (1996): meaning product, price, promotion, and place. In this sense, in addition to the product, a crucial variable of the marketing compound is price. The place (trading center, distribution) is another key-variable of the marketing compound; it includes the set of activities accomplished by the company to make the product accessible and available, supplying the time and place factors. The promotional compound comprehends the activities aimed at informing and persuasively communicating the company's supply to the target-market (McCARTHY, 1996).

An important aspect in marketing compound management, pertinent to the marketing planning process, refers to the issue of deciding upon the allocation of the marketing budget, among the several products, channels, and sales promotion instruments (WESTWOOD, 2005).

Campomar (1984) suggests a systemic representation of the operational process, which allows for obtaining a dynamic idea of the flows that determine the exchange system, in addition to evidencing the uncontrollable external variables, which can provoke favorable or unfavorable impacts upon the company's relationships with its respective markets. Under a strategic perspective, the marketing system requires an examination of the market in terms of tendencies, events and market demands, as well as the opportunities offered in the long term. In this case, the analysis work is prospective, and its objective is to raise and appraise market segments to be profitably exploited by the company, in consonance with its resources and objectives. As a result of the analysis of the marketing opportunities and the assessment of 
the company's competitive potential, in comparison with the competition, it will be enabled to decide on the position it will take in the market, in relation to competitors, so as to form a differentiated image in terms of product, price, promotion and area of delivery.

Marketing planning is operational and subordinate to strategic planning, which is broader, more encompassing and more long-term. However, marketing planning and, therefore, its activities, are elevated to the strategic level when the demand is smaller that the company's supply, and can then be called "Strategic marketing planning".

At the strategic level of functional marketing structures, two closely related concepts stand out: market segmentation and positioning (HOOLEY, SAUNDERS and PIERCY, 2005). The concept of segmentation points to a process that develops from a phase characterized as the partition of the target-market, identified in marketing texts as segmentation. This stage of the strategic and competitive marketing process refers to raising the segmentation variables and designing the profile of the market segments that could be reached by specific marketing compounds.

In a second stage, there is a priority decision to be made; in this stage one seeks to accomplish a strategic choice of segments, in order to obtain a competitive edge. The process culminates with the positioning stage. Thus, the segmentation and positioning processes constitute the core of the company's strategic marketing and the essence of the company's achieving greater competitiveness (HOOLEY, SAUNDERS and PIERCY, 2005). It is in the context of this strategic dimension that market segmentation proves to be of importance for marketing planning, particularly in formulating and implanting marketing strategies for specific markets (PETER and DONNELLY, 2002; MCDONALD and DUNBAR, 1995).

\subsection{Marketing planning}

As to the issue of strategy, Harrison (2005) suggests that it can be conceived as a sequence of decisions in time. Alternatively, as a process that involves a set of actions aimed at pushing a company towards fulfilling its short-term goals and long-term objectives.. Still according to the same author, strategies present themselves in all organizations, both the simplest as the largest and most complex, but they may vary in terms of the degree of formalism with which they are formulated and implanted. In some companies, especially those which operate in rapidly changing environments, or in small-scale organizations, strategies are not described as "planned", according to the formal conception of the term.

In addition to the degree of formality, strategies can be considered in terms of being deliberate o emergent (HAX and MAJLUF, 1996). In deliberate strategy, managers plan to follow a certain predefined and intentional course of action. An emergent strategy means that it is not necessarily planned or intentional, but the result of patterns and consistencies observed in the past, through a trial and error process. These last two concepts constitute the limits of the different combinations that form the basis for a typology that characterizes strategy formulation processes.

Strategy formulation, conceived as a process of planning strategies, or, in the broadest sense, the process of strategic planing, can be dismembered into three levels: corporate, company-wide or pertaining the strategic business unit (SBU), and functional (KOTLER and KELLER, 2006).

At the corporate level, the formulation of the strategy (strategic planning) refers to the definition, assessment and selection of business areas in which the organization will compete, 
and the emphasis that should be placed on each area. At this level, the main issue is the allocation of resources among the organization's business areas, according to the criteria of attractiveness and competitive position of each of the areas, and the strategies are predominantly aimed towards the growth and permanence (survival) of the organization.

Strategic formulation at the second level - of the company or the strategic business area - is related to the effective use of the resources and refers to the direction towards which the company will aim the business scope. At this level, the so-called competitive strategies prevail. Thus, the single business strategy refers to the way in which the organization will compete in the chosen markets.

Strategic formulation at the functional level relates to the process through which the company's several functional areas will use their resources to implement the company's strategies, so as to gain a competitive edge and contribute towards the growth of the organization. Thus, for example, in each business unit, the functional marketing area will develop the planning process bearing in mind the formulation of its strategies em the achievement of the objectives of the single business in specific markets (KOTLER and KELLER, 2006).

In medium-scale companies with one single SBU, strategic marketing planning and operational marketing planning can be developed as a single process (STEVENS et al., 2001), and, in smaller organizations, the planning process incorporates the three levels simultaneously. Harrison (2005) adds to this, stating that when dealing with strategies in the scope of the corporation, decisions are reached at the highest levels of the organization, although the people at that level may receive information from managers at lower levels. If a certain organization has only one business unit, the first and second level decisions are made by the same people. In organizations with multiple businesses, decisions at the business unit level are made by the highest-level executives in the unit; at the functional-area level decisions are made by the respective managers.

\subsection{Marketing organizational structure}

An important aspect to be considered in company and marketing planning processes is the issue of the administrators' participation in the process as a whole. Stevens et al. (2001) argue that, in general, the more the organization grows, more the planning activity is placed under the charge of groups of managers, instead of each manager individually. These authors point out a few reasons for the fact that larger-scale organizations recur to a professional planning team. In the first place, planning takes time, and, therefore, a planning team can reduce the managers' individual workload. A second reason is that planning requires coordination, and a specialized team can help integrate and coordinate each manager's planning activities. Also, since planning requires experience, a team can contribute with a larger number of instruments and techniques towards the solution of a certain problem, than a single individual. A fourth reason refers to the fact that planning requires objectivity; in this case, a planning team can have a wider scope of vision than a single individual.

Campomar (1984) affirms that an organization implanting a marketing strategy presupposes the existence of a structure to operationalize activities. It is through the coordination of the people involved in the structure that the marketing compound decisions take place.

Stevens et al. (2001) argue that coordination in the firm involves an ordering of combined efforts to reach a common purpose, through the members of an organization. These efforts are shared among the individuals in an orderly way, attributing to each a specific function 
in the implantation of the marketing compound. The way of coordinating the people involved in the marketing activities is influenced by the philosophies adopted by the organizations, and may place emphasis on production, sales, innovation, or be aimed at marketing. Additionally, marketing structures are subordinate to the organization's general organizational structures and, accordingly, are aligned with the existing competitive and corporate strategies (STEVENS et al., 2001). This reasoning leads one to believe that the execution of marketing activities may be diluted in other departments, such as sales, production, institutional communication, P\&D, finances, etc. of the company, and the marketing managers lack, many times, the power to alter the existing structures.

The marketing area's structure may take on different shapes, depending upon the emphasis given to the type of coordination and control intended by the organization. Boyd and Massy (1972) classify marketing structures into four different groups: functional, products administration, markets administration and general administration. McDaniel (1979) describes the existence of some structures: product based, functional, geographically divided, and the matrix-based form. Davis (1981) classifies four ways of organizing the marketing structure: functional, product, market and mixed (product and market).

Among the ways of organizing the marketing structure, the most traditional are the functional structure, product structure and market structure. The first is departmentalized by activities (sales, promotion, marketing research, marketing planning). There is an executive responsible for the organization's total marketing effort and those responsible for each one of the activities are subordinate to it. The second case occurs when the organization has a varied production, that is, there are several products and brands. As the complexity or resource administration increases, for each one of these products, the organization finds itself compelled to delegate a product manager for markets to each group. This happens when the organization offers its products to a set of highly diversified markets. In this case, the organizational structure should allow specialization per market, with areas aimed at each one of them.

According to Achrol (1991), in spite of the changes in the marketing environment during the end of the last century, many times, organizational structures are still developed on functional bases. The author advocates that, in a dynamic environment, those forms should be revised.

Ruekert, Walker Jr. and Roering (1985) have developed a contingency-based approach to restructure these activities within the several environmental settings and the proposed organizational objectives. According to the authors above, structures can take on bureaucratic, organic, transactional a relational forms. Where:

In the bureaucratic form, structures are rigid, formalized and loosely integrated. Central control is used to monitor and assess the result, activities are distributed in a traditional way, such as, for example, a sales department;

In the organic form structures are decentralized, non-formalized and based on specialized groups. Activity planning takes place at low levels of the organizational hierarchy. Marketing, P\&D, market research, and production specialists are appointed for the creation of workgroups, and there may be a product manager leading the process in more centralizing companies. In this case, those structures can be termed matrix-oriented structures.

In the transactional form, structures take into consideration internal organizational aspects and the employment of outside organization companies. A transactional form is defined by centralized, formalized structures, without much interaction among the parts. Activities are normally carried out under standard contracts. The most usual forms are: system activities and marketing information activities, channels administration, etc. are delegated to third parties; 
In the relational form, the structures are similar to the transactional ones. However, they are little centralized and formal, and their parts are more integrated. An example of the composition of such structure is in the establishment of a strategic relationship with a publicity agency.

Organizational structures are moving towards an ever more fluid situation, based on hybrid structures that can take on different designs (DAY, 1999). Also, marketing activities are less and less concentrated in departments or identified with specific employees in the organization (GUMMESSON, 2005).

In spite of the present paradigm, which places great importance on marketing philosophies within companies' corporate and competitive strategies, organizations' structures tend to dissolve the existing marketing departments. According to Webster Jr., Malter and Ganesan (2005), "currently, marketing in many large companies is less a department, and is more a Diaspora of abilities and capacities dispersed inside and outside of organizations".

The same authors report that, in many organizations, marketing has been loosing budget and influence over the authority structure and suffering several downsizing processes. Many of the traditional marketing activities, such as account and customer administration, product development, price definition and distribution, are being moved to other areas of the strategic business units. Functions related to marketing information systems are sometimes included in the marketing assignments, sometimes excluded, and, lastly, most companies are reducing their marketing areas to brand management and communication areas (WEBSTER JR., MALTER and GANESAN, 2005).

Webster Jr., Malter and Ganesan (2005) list, as the main causes of changes in organizational structures: The pressure for short-term financial results (purchasing business units well-placed in markets, instead of developing new businesses); The difficulties marketing areas find in measuring their productivity; the changes in power and control within value systems; the difficulty present marketing structures find in moving towards and efficient administration of client relationships; the deflection of organizational resources from marketing to sales; the strengthening of a client and value-based orientation in management structures, so that such issues no longer appear as belonging to the marketing area.

\subsection{Relationship between marketing planning, strategies, and innovative organizational structures}

The theoretical review presented indicates that marketing activities are executed around philosophies and strategies formulated by companies. Those strategies and philosophies result in organizational arrangements that can be grouped into traditional or innovative forms. Also, competitive strategies based on lock-in systems or contract theories justify the existence of innovative organizational structures that are not limited to a single organization or to functional bases. On the other hand, marketing activities do not change throughout these several structural options. Marketing functions are carried out independently from the departments involved, which includes marketing planning activities. Therefore, what will determine the organizational formalizing and awareness building around planning activities, and not their existence, will be the way in which the organization views marketing within its strategic vision.

In structures whose philosophy and competitive strategies are not geared towards marketing, in those in which the organizational structure is based on organic models, transactional or relational, and, finally, in the customer-oriented companies, where marketing departments 
have been pulverized throughout the structure or outside of it, planning activities will be present in several organizational departments or clusters.

John and Martins (1984) carried out a study around this issue. These authors investigated the effects of the organizational structure's credibility on marketing planning. The results of this work indicate that organizational formalizing, through clear rules and procedures, improves the use of this activity and its efficient employment. Restrictions were placed around the bureaucratization of authority concentration structures. The work indicated that levels of specialization are positive for the plan to be well accepted, but that excesses can engender negative assessments of its credibility (JOHN and MARTINS, 1984).

The dilemma between the need to structure planning and the tendency to deal with more and more complex and innovative organizational structures suggests the creation of an organizational formalization instrument that will help identify those responsible for carrying out marketing planning, without the need for a marketing department. An alternative proposed for this end is the formulation of marketing planning through its structural context, in connection with its most relevant activities, where procedures and rules can be assessed and executed (JOHN and MARTINS, 1984). This context can be identified by a matrix that associates activities related to planning, such as collaborators or areas responsible for its implantation and control.

There are several instruments for formalizing activities and responsibilities that can help the organization formalize its administrative activities, independent from traditional organization charts, and which are useful in increasing the organizational formalizing of marketing planning (VASCONCELLOS and HEMSLEY, 2002). Among them, one can point out the functional organizational chart and the ARF - administrative flow chart (BARNES et al., 1970). Where the first includes a set of roles or positions aligned in columns and a set of responsibilities and authorities in lines. The cells formed in this matrix reflect different persons' situation in regards to the activities, which are: the individual responsible for the execution and/or decision upon the activity, the individual who must be consulted before and after the decision and/or execution of the activity, the individual who must be informed after the decision and/or execution of the activity, among other possibilities. The second instrument is similar to the first, but employs administrative procedures existing during an administrative action, that is, the activities are placed according to the order of their execution on the columns and those responsible for the decision, retention, direction, delegation and action are listed on the lines.

As an example for the application of these instruments in marketing planning, the AFC lines could be determined in accordance with the description of the planning activities, such as segment identification, target-market choices and marketing positioning. As for the columns, they could adequate to the prevailing structural organizations in the companies, such as sales, finances and communications departments, etc., or even include external activities such as the employment of research institutes and publicity agencies.

\section{Issues adjacent to marketing planning and the organizational structure}

The objective of this section is to critically analyze, not the method or process itself, but certain adjacent issues correlated to the process, which are however contemplated only in an accessory and complementary way, in texts by specialists.

One of the questions raised here is directly linked to company planning and the role of marketing administration. Lambin (2000) firmly believes that to remain competitive it is 
necessary to plan and, accordingly, Kotler and Keller (2006) state that marketing has the function of leading the process of staying competitive.

During the analysis of the available bibliographical material pertaining to the development of the theme, a consensus was observed between professional and entrepreneurial theorists: That it is necessary to redirect planning techniques and management processes in order to encourage the marketing strategy; the realization of consistent forecasts and adjustments of the corporate resources to new market opportunities.

However, some contrary ideas and positions were also identified, especially within the scope of small and medium-scale companies. Among them, the idea that planning requires efforts that could not be fulfilled in short spaces of time stands out. Also, the scarcity of resources to carry out a formal planning activity may be a limiting factor.

In spite of the questions as to the relevance of planning, the benefits of such a process are indisputable for Lambin (2000). Still according to the author, strategic and marketing planning both allow for assessing the company's position in the market, identifying favorable and unfavorable situations coming form the external environment, assessing ones strengths and weaknesses, and concluding therefrom on present and future threats and opportunities.

The author also recalls that planning favors the establishment of goals, objectives, priorities and strategies, in addition to leading to collaborators (employees) effectively committing to any change in the company.

Another question concerns the possibility of planning retarding actions and causing some administrators to feel curtailed, and, consciously or unconsciously, not allowing selfinitiative and an enterprising and innovative spirit to surface.

Lambin (2000) suggests not a criticism of planning itself, but a limitation inherent to some organizations that makes the process o planning difficult. This limitation is related to the fact that some companies find it impossible to build a marketing information system that makes it possible to constantly monitor the movements of the competition, the market and the other forces and entities in the external environment. Still according to the author, a marketing information system may be an indispensable requirement for the company's management, in seeking competitive edges.

One characteristic of companies that employ formalized operational marketing planning is that they do this in the form of a marketing plan. As proposed by Campomar (1983), the activities inherent to a marketing plan include carrying out an analysis of the situation, determining the objectives, developing the strategies, deciding upon action programs for the components of the marketing compound and preparing supporting financial displays (budgets and profit and loss projections).

The plan, as the advocated by the author, is the formal document, which substantiates the mental process of marketing planning. In this context, an objection is raised against the rigidity and the authoritarian and formal conception of the plan and planning process. Thus, a company, when putting a plan into action, is risking consolidating a bureaucratic attitude and behavior, which, by its very nature, is the opposite of the desirable flexibility necessary to deal with unstable environments.

The importance of planning, according to Campomar (1984), Lambin (2000) and Kotler and Keller (2006), is a fact, whether in the process of re-structuring organizational hierarchies, or in the creation of new products and services, or even in deciding on new ways of pricing the products offered. As refers to adopting new organizational configurations in order to remain competitive, companies must plan, and the formalizing of planning may or may not result in a marketing plan. 
As refers to the use of innovative hierarchies by organizations, Hooley, Saunders and Piercy (2005), recall that innovation may be uncertain, that is, it would not be possible without management. However, the same authors point out that the more and organization looks for innovation, the more experience it will accumulate, and, consequently, it will be more able to manage innovative processes and remain competitive.

In accordance with the authors, one assumes that innovation needs not be planned, since that would be very hard to manage. However, throughout the organization's natural lifecycle, it begins to acquire the capacity to manage new processes of innovation and planning becomes lighter, independently of the structure formed for its conception.

\section{Final considerations}

The strategic process in an organization is a permanent process of adjustment and adaptation of its objectives and resources, competencies and capacities, to the opportunities offered by the changing business environment.

Planning, at the strategic, tactical, and operational levels, shows itself as a mechanism that allows for the adjustment, aimed at gaining sustainable competitive edges, and consequently attaining growth and profitability, in an environment characterized by uncontrollable and unforeseen changes. In such cases, marketing is raised to the strategic level.

It is timely to point out that strategic planning and marketing planning are key parts in the context of the management process at its several hierarchical levels.

In that respect, marketing planning, in organizations geared towards clients or markets, plays a central role in the system, as an inseparable instrument in the process of formulating and implanting competitive and growth strategies and as an agent that facilitates and maintains upcoming organizational changes, even in innovative structures that no longer have a functional marketing department.

The present article did propose to analyze all the chains of thought in the discussion on strategy, organizational structures and marketing planning. The intention was to bring to light a discussion around the relationship between these concepts, and, specifically, between them and innovative structures. The hope is that the insights generated throughout this study can contribute to the development of marketing and of future studies in the area. The aim was to clear up the differences between the several strategic levels in the formulating of corporate, competitive and functional strategies, in addition to situating the marketing planning process in the organizational structure. Also analyzed were the effects of these strategies in the companies' structural arrangements. In this way, the fostering of organizational structures around classic clusters, like the functional one, or aimed at innovation, may go beyond the borders of companies' properties.

Permeating the discussion above, the article "brought to light" some aspects of the function and activities of marketing that are related to the activities of marketing planning and organizational structure. Finally, the text brought forth a direct reflection about the relationship between marketing planning, and innovative organizational strategies and structures, and briefly described the ways of enhancing its execution in innovative structures. The considerations made upon the authors were based on the interpretation of the sources and evidences consulted, and are, therefore, guided by the conception of the researcher and, occasionally, subject to bias, in some statements, and, since this research has been of an exploratory nature, the results mentioned above should not be generalized. Since it is an academic work structured as an essay, the intention was not to carry out any analytical descriptive or illustrative exploratory 
research, in connection with the case-study method. The essay has been a theoretical and provocative contribution, the intention of which is to waken the theoretical and investigative spirit of future researchers. For a better contribution to the state of the art in administration, it is suggested that single-case or multi-case case studies be carried out, in order to validate future hypothesis the essay may have instigated in the reader.

\section{Referências}

ACHROL, Ravi S. Evolution of the marketing organization: new forms for turbulent environments. Journal of marketing, 55, p. 7793, Oct. 1991.

AMA. AMERICAN MARKETING ASSOCIATION. Marketing glossary dictionary. Source in: <http://www.marketingpower.com/live/mgdictionary.php?>. Acessed in: 24 Jan. 2006.

ANSOFF, H.I. Strategies for diversification. Harvard Business Review, Cambridge, Massachusetts, v. 43, Issues 2-3, p.113-124, Sep./ Oct. 1957.

BARNES, M. C. et al. Company organization: theory and practice. London: Allen and Unwin, 1970.

BESANKO, D.; DRANOVE, D.; SHANLEY, M. Economics of strategy. 2. ed. New York: Wiley, 2000.

BOYD JUNIOR, H.W.; MASSY, W. F. Marketing management. New York: Harcourt Brace Jovanovich, 1972.

CAMPOMAR, M. O sistema de marketing. Revista Marketing, São Paulo, v.18, p. 43, 1984.
DAVIS, K. R. Marketing management. 4. ed. New York: Wiley, 1981.

DAY, George. Aligning organizational structure to the market. Business Strategy Review, v. 10, n. 3, p. 33-46, 1999.

FINK, S.; JENKS, R. S.; WILLITS, R. D. Designing and managing organizations. Homewood: Irwin, 1983.

GALBRAITH, J. R. The essential galbraith. Columbus, OH: Mariner Books; Addison-Wesley, 2001.

GREINER, L. Evolution and revolution as organizations grow. Harvard business review, v. 23, issues 5-6, Cambridge, Massachusetts, p. 5567, May/Jun. 1998.

GUMMESSON, E. Marketing de relacionamento total. 2. ed. Porto Alegre: Bookman, 2005.

HARRISON, J. S. Administração estratégica de recursos e relacionamentos. Porto Alegre: Bookman, 2005.

HAX, N. S.; MAJLUF, A. C. The strategy concept and process: a pragmatic approach. 2 nd. ed. Columbus, OH: Prentice Hall, 1996.

HOOLEY, G. J.; SAUNDERS, J. A.; PIERCY, N. F. Estratégia de marketing e posicionamento 
competitivo. São Paulo: Pearson- Prentice Hall, 2005.

ITO, K.; ROSE, E. L. An emerging structure of corporations. The Multinational Business Review, v. 12, n. 3, p. 63- 83, Winter 20042005.

JOHN, G.; MARTIN, J. Effects of organizational structure of marketing planning on credibility and utilization of plan output. Journal of Marketing Research, v. 21, p. 170-183, May 1984.

KOTLER, P.; KELLER, K. L. Administração de marketing. São Paulo: Prentice Hall, 2006.

LAMBIN, J. J. Marketing estratégico. Lisboa: McGraw Hill, 2000.

MCCARTHY, E. J. Basic marketing: a global managerial approach. Columbus, OH: McGrawHill, 1996.

MCDANIEL JR, C.. Marketing: an integrated approach. New York: Harper \& Row, 1979.

MCDONALD, M.; DUNBAR, I. Market segmentation: a step-by-step approach to creating profitable market segments. London: Macmillan Business, 1995.

MEDEIROS, J. B. Redação científica: a prática de fichamentos, resumos, resenhas. 2. ed. São Paulo: Atlas, 2000.

MINTZBERG, $\mathrm{H}$. The strategy process:

concepts, context, cases. 4th. ed. Columbus, $\mathrm{OH}$ : Prentice Hall, 2002.

MORGAN, G. Imagin-I-Zacion (Management, Granica), Madrid: Granica, 1999.

PETER, J. P.; DONNELLY, J. H. Preface to marketing management with PowerWeb. New York: McGraw-Hill//rwin, 2002.

PORTER, M. E. Competitive advantage: creating and sustaining superior performance (hardcover). Atlanta, GA: Free Press, 1998.

PRAHALAD, C. K. The future of competition: co-creating unique value with customers (hardcover). Cambridge: Harvard Business School Press, Feb. 18, 2004.
RUEKERT, R. W; WALKER JR, O. C; ROERING, $K$. The organization of marketing activities: a contigency theory of structure and performance. Journal of Marketing, v. 49, p. 13-25, Winter 1985.

\section{SEVERINO, A. J. Metodologia do trabalho} científico. São Paulo: Cortez, 2000.

STEVENS, R. et al. Planejamento de marketing. São Paulo: Makron Books, 2001.

TOLEDO, G. L.; FORTES, W. G. Relações públicas e marketing: uma abordagem estratégica. Revista de Administração, São Paulo, v. 24, n. 3, p. 1-10, jul./set. 1989.

TOLEDO, G. L; QUELOPANA, E.M; POLERO, A.C. Diferentes estrategias para el éxito dentro de un holding latino americano. Estudio del actual líder en I+D+I. In: REUNIÃO ANUAL DA ASSOCIAÇÃO NACIONAL DE PROGRAMAS DE PÓS-GRADUAÇÃO EM ADMINISTRAÇÃO, 2005. Anais... Brasília, 2005.

VASCONCELLOS, E.; HEMSLEY, J. R. Estruturas das organizações. São Paulo: Thomson, 2002.

WEBSTER JR, F. E; MALTER, A. J; GANESAN, $S$. The decline and dispersion of marketing competence. MITSloan management review, $\mathrm{v}$. 46, n. 4, p. 35-43, Summer 2005.

WESTWOOD, J. The marketing plan workbook: The Sunday Times Business Enterprise Guide Series). New York: Kogan Page, May 31, 2005. 